\title{
New gall midges (Diptera, Cecidomyiidae) associated with Eugenia uniflora and Psidium cattleianum (Myrtaceae)
}

\author{
Valéria C. Maia ${ }^{1} \&$ Dori E. Nava ${ }^{2}$ \\ 1. Departamento de Entomologia, Museu Nacional, Quinta da Boa Vista, São Cristóvão, 20940-040 Rio de Janeiro, RJ, Brazil. \\ (maiavcid@acd.ufrj.br) \\ 2. EMBRAPA Clima Temperado, Rodovia BR 392, km 78, Caixa Postal 403, 96001-970 Pelotas, RS, Brazil. (nava@cpact.embrapa.br)
}

\begin{abstract}
Two new species and a new genus of gall midges (Diptera, Cecidomyiidae) are described and illustrated. Both species induce leaf galls on Myrtaceae, the former on Eugenia uniflora and the latter on Psidium cattleianum.
\end{abstract}

KEYWORDS. Araçá, gall, Neotropical, pitangueira, taxonomy.

RESUMO. Novos insetos galhadores (Diptera, Cecidomyiidae) associados a Eugenia uniflora e Psidium cattleianum (Myrtaceae). Duas novas espécies e um novo gênero de insetos galhadores (Diptera, Cecidomyiidae) são descritos e ilustrados. Ambas espécies induzem galhas foliares em Myrtaceae, a primeira em Eugenia uniflora e a segunda em Psidium cattleianum.

PALAVRAS-CHAVE. Araçá, galha, Neotropical, pitangueira, taxonomia.

Eugenia uniflora (Myrtaceae) is popularly known as pitangueira. It occurs in Brazil (from Bahia to Rio Grande do Sul), Uruguay, Paraguay, and Argentina (MARCHIORI \& Sobral, 1997). Its fruits are eatable and used in the manufacturing of soft drinks and jelly.

Several morphotypes of Cecidomyiidae galls have been recorded in Brazil on this host plant: young leaf rolls (HouARD, 1933, fig. 618); conical leaf galls (MAIA, 2001, fig. 62); circular leaf galls (MAIA, 2001, fig. 63); triangular fruit galls (MAIA, 2001, fig. 64); elliptical leaf galls (RÜBSAAMEN, 1917, p.130, 131, nr. 31), spongy leaf galls (MAIA et al., 2008, fig. 98) and triangular leaf galls.

Only three gallers are identified at specific level, the others remain at family level. In this paper, the inducer of the triangular leaf galls is identified as a new species of Eugeniamyia Maia, Mendonça \& Romanowski, 1996 which is described and illustrated (male, female and larva).

Eugeniamyia was known, until this moment, from one species, E. dispar Maia, Mendonça \& Romanowski, 1996, which induces leaf galls on Eugenia uniflora. This genus has a very peculiar male terminalia (MAIA et al., 1996, fig. 7, p.1089); ovipositor short, barely protractible, and separate female cerci with strong setae at the apex and otherwise covered with sparse setae. These characters are also presented by the new species.

Psidium cattleianum (Myrtaceae), popularly known as araçá, is native to the Atlantic forest of southeastern Brazil, extending from the state of Espírito Santo in Brazil to Uruguay (20-32º') (MARCHIORI \& SOBRAL, 1997; REITZ et al., 1983). Although not cultivated commercially on a significant scale, $P$. cattleianum has been cultivated for its fruit and ornamentally. It is also a popular fuel wood (HodGes, 1988).

Five insect galls have been recorded on this plant, namely: 1) leaf gall induced by Tectococcus ovatus Hempel, 1990 (Hemiptera, Eriococcidae); 2) fruit gall induced by Eurytoma psidii Wikler, 1999 (Hymenoptera, Eurytomidae); 3) stem gall induced by Eurytoma sp. (Hymenoptera, Eurytomidae) (WIKLER, 2007); 4) rosette gall induced by Dasineura gigantea Angelo \& Maia, 1999 (Diptera, Cecidomyiidae), and 5) spherical leaf galls induced by Neotrioza tavaresi Crawford, 1925 (Hemiptera, Psyllidae).
A new genus and species of midge that induces cylindrical leaf galls on P. cattleianum was found in Rio Grande do Sul. This galler is also described herein (male, female and pupa). It belongs to the supertribe Lasiopteridi, but it does not fit in any known tribe.

\section{MATERIAL AND METHODS}

Triangular galls on leaves of $E$. uniflora were collected in August, 2000 in the restinga of the Barra de Maricá, Maricá, southern, Brazil. To obtain adults, part of the samples was taken to the laboratory and kept in plastic pots layered at the bottom with restinga soil (as the larvae drop to the soil and pupate on the ground) covered by a fine screening.

Cylindrical leaf galls on P. cattleianum were collected in December, 2008 and January, 2009 in Pelotas, southern, Brazil. The samples were placed in plastic bags and transported to the laboratory, where some galls were dissected under a stereoscopic microscope to obtain immature stages of the galling insect. Adults were obtained by keeping some samples in plastic pots (300 $\mathrm{ml}$ ) layered at the bottom with a $1 \mathrm{~cm}$ solution $5 \%$ agar/ water and covered by a plastic film. All pots were daily checked to verify galler emergence. Larvae, pupae and adults were preserved in $70 \%$ alcohol.

The specimens were prepared and mounted on slides following the methods of GAGNÉ (1994). All material, including the types, are incorporated in the Diptera collection of Museu Nacional, Rio de Janeiro (MNRJ). Terminology of the adults follows MCALPINE (1981) and that of the immature stages follows GAGNÉ (1989).

\section{RESULTS}

\section{Eugeniamyia triangularis sp. nov.} (Figs 1-8)

Adult. Body length: $1.80 \mathrm{~mm}$ in male $(\mathrm{n}=1) ; 1.70$ $2.60 \mathrm{~mm}$ in female $(\mathrm{n}=5)$.

Head. Post occipital peak absent; eye facets circular, 
facets not closely appressed at the vertex and laterally; antennae: scape obconic; pedicel globose; number of flagellomeres: 12 in male, 14 in female, flagellomeres cylindrical, with 2 connected ring-circumfila in both sexes; male flagellomeres with long neck (about $1 / 2$ of node length, Fig. 1); female flagellomeres with short neck (about $1 / 4$ of node length, Fig. 2); necks bare and nodes setulose. Flagellomeres 1 and 2 connate. Last flagellomere without apical process. Palpus with four setose segments, first segment triangular, second rectangular, third claviform and fourth conical. Thorax: anepimeron setose, other pleural sclerites asetose. Wing (Fig. 3) length: $1.20 \mathrm{~mm}$ in male ( $\mathrm{n}=1)$; 1.20-1.65 mm in female $(n=6)$; $R 5$ reaching the costal margin after wing apex, Rs absent; M3 fold present, CuA forked, $\mathrm{CuP}$ present. Tarsal claws toothed, empodium well developed (Fig. 4). Male abdomen: tergites 1- 6 rectangular with a single, complete row of caudal setae, some lateral setae, two anterior trichoid sensilla and elsewhere with scattered scales. Tergite 7 with reentrance at anterior margin and two anterior trichoid sensilla. Tergite 8 band-like with only two anterior trichoid sensilla as vestiture. Sternites 2-7 rectangular and setose, setae more abundant anteriorly and mesally, and two anterior trichoid sensilla. Sternite 8 slightly curved with scattered setae and two anterior trichoid sensilla. Female abdomen: tergites 1-7 rectangular, tergite 8 squarish, all with a single, complete row of caudal setae, some lateral setae, two anterior trichoid sensilla and elsewhere with scattered scales. Sternites 2-7 as in male. Sternite 8 not sclerotized. Male terminalia (Fig. 5): gonocoxite wide with a mesobasal lobe; gonostylus pyriform, completely setulose; lobes cercal ovoid, hypoproct almost entire; aedeagus rounded at apex. Ovipositor barely protrusible; cerci ovoid, $0.05 \mathrm{~mm}$ of length and $0.03 \mathrm{~mm}$ of width (Fig. 6).

Pupa. Unknown.

Larva. Body elongate, cylindrical, tapered at both ends, more prominent at anterior end. Length: 2.20-2.30 $(n=2)$. Integument rough. Spatula $0.14 \mathrm{~mm}$ of length $(n=1)$, with two well-developed apical teeth and elongate stalk; only three lateral papillae per side (Fig. 7). Terminal segment convex, with a pair of setose terminal papillae and two pairs of asetose anal papillae (Fig. 8).

Type material. Holotype $\sigma^{\top}$. BRAZIL, Rio de Janeiro: Maricá (Restinga da Barra de Maricá), 27.VIII.2000, Maia \& Azevedo col. (MNRJ). Paratypes: same data as holotype, 39, 2 larvae; 25.VIII.2000, Maia \& Azevedo col., 49. Obtained from triangular leaf galls on Eugenia uniflora.

Etymology. The name triangularis refers to the shape of the gall

Remarks. The adults of E. triangularis differ from those of $E$. dispar mainly in the number of flagellomeres (12-14 in the former and 14-18 in the latter), wing venation (M3 and CuP present only in the new species), shape of gonostylus (more curved in the E. triangularis), width of male hypoproct and male cercal lobes (both are slender in the new species). The larvae of both species are very distinct, differing in the shape of the larval spatula (twotoothed in the new species and without apical teeth in $E$. dispar) and number of terminal papillae (two in the new species, and eight in E. dispar).
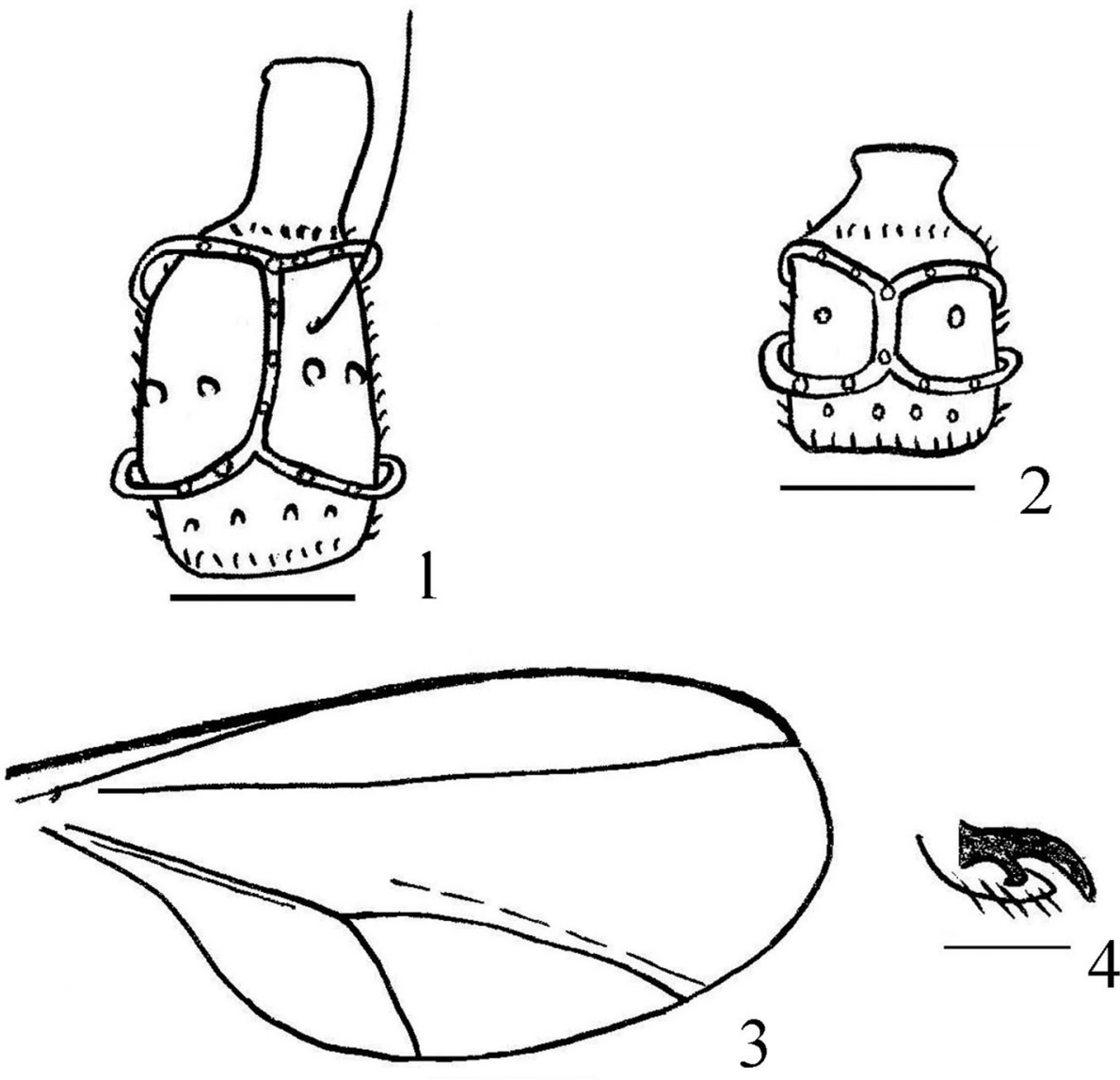

Figures 1-4. Eugeniamyia triangularis sp. nov. 1, male flagellomere 5 (scale bar: $0.03 \mathrm{~mm}$ ). 2-4, female: 2, flagellomere 5 (scale bar: 0.03 $\mathrm{mm}$ ); 3, wing (scale bar: $0.50 \mathrm{~mm}$ ); 4 , hind leg, tarsal claw and empodium (scale bar: $0.02 \mathrm{~mm}$ ). 

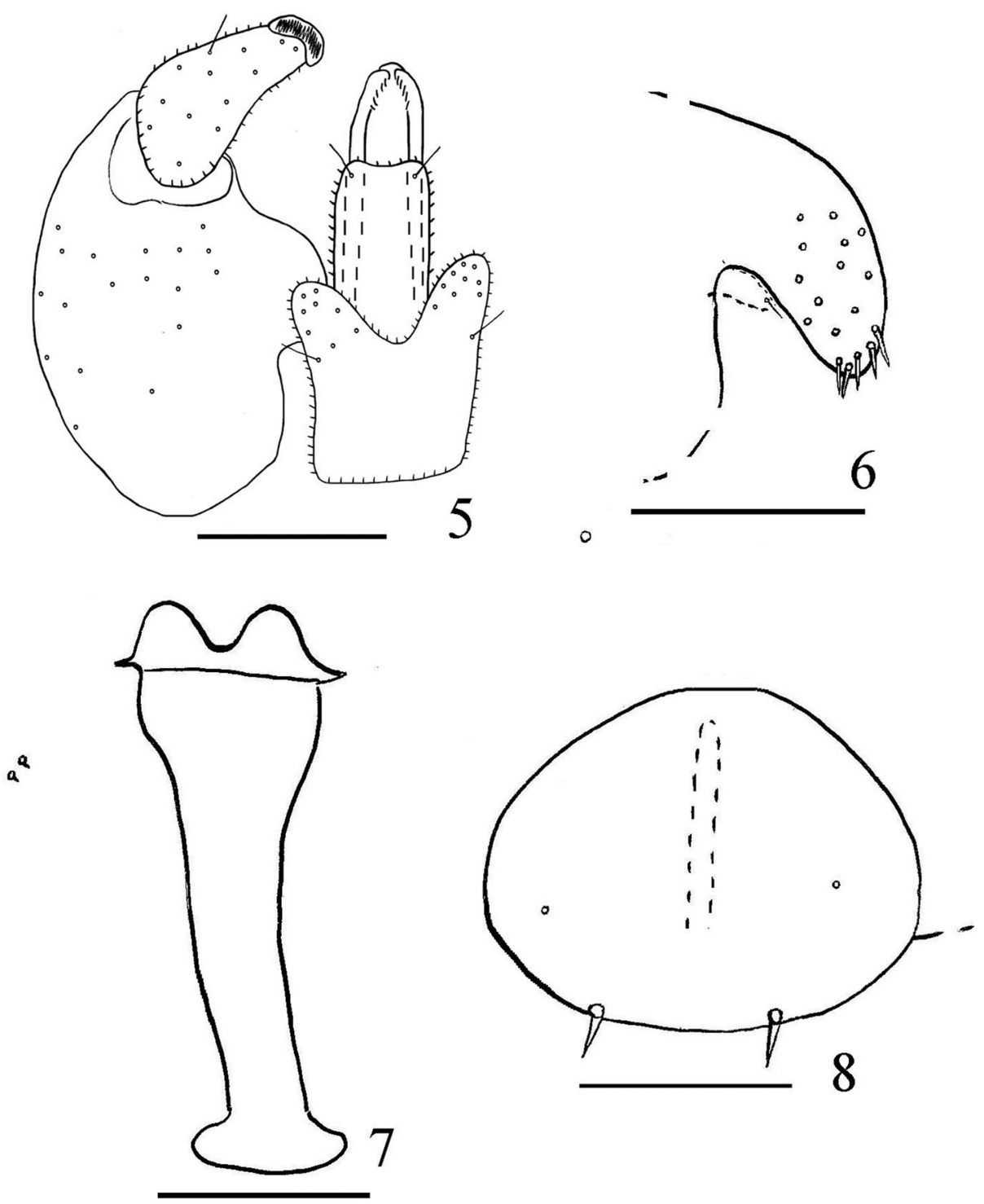

Figures 5-8. Eugeniamyia triangularis sp. nov. 5, male terminalia, dorsal (scale bar: $0.05 \mathrm{~mm}$ ); 6 , female cerci, lateral (scale bar: $0.05 \mathrm{~mm}$ ); 7, larva, spatula and associated papillae, ventral (scale bar: $0.05 \mathrm{~mm}$ ); 8, larva, terminal segment, ventral (scale bar: $0.10 \mathrm{~mm}$ ).

\section{Elachypalpus gen. nov.}

Diagnosis. Palpi one-segmented; tarsal claws onetoothed; short ovipositor; male hypoproct slightly bilobed; female cerci elongate-cylindrical; pupa: antennal horns and prothoracic spiracles reduced; dorsal abdominal spines absent; larva: prothoracic spatula reduced and two-toothed.

Adult. Eye facets circular, facets not closely appressed at the vertex and laterally. Flagellomeres cylindrical, with 2 connected ring-circumfila in both sexes. Palpus onesegmented. R5 reaching the costal margin after wing apex, Rs absent; $\mathrm{M} 3$ fold present, $\mathrm{CuA}$ forked, CuP present. Tarsal claws toothed, empodium well developed. Male terminalia: gonocoxite wide with mesobasal lobe; gonostylus claviform, completely setulose; lobes cercal triangular, hypoproct slightly bilobed; aedeagus round at apex. Ovipositor barely protrusible; cerci separate, elongate-cylindrical and setose, with two pairs of strong setae at apex. absent.

Pupa. Antennal horn short; dorsal abdominal spines

Larva. Spatula prothoracic two-toothed with reduced stalk, two setose terminal papillae.
Etymology. The name Elachypalpus is composed by elachys (= short) + palpus. It refers to the length of the palpi.

Remarks. Lasiopteridi comprise 9 tribes (Alycaulini, Camptoneuromyiini, Dasineurini, Lasiopterini, Ledomyiini, Oligotrophini, Poomyini, Rhopamyiini and Trotterini) and 54 unplaced genera (21 known from the Neotropics) (GAGNÉ, 2004).

These unplaced genera were previously included in the tribe Oligotrophini, which was a heterogeneous assemblage with no apomorphic character. GAGNÉ (2004) redefined this tribe, limiting it to four genera and 16 species associated with Cupressaceae, all with simple tarsal claws with very long empodia (none of them occur in the Neotropical region).

Among the Neotropical unplaced genera, nine have elongate-protrusible ovipositor, and the others have short, not or barely protrusible ovipositor, except for Angeiomyia Kieffer \& Herbst, 1909 whose female is unknown. The Neotropical unplaced genera with short ovipositor are: Eugeniamyia; Guareamyia Maia, 2007; Guarephila Tavares, 1909; Haplopalpus Rübsaamen, 1916; Jorgenseniella Maia, 2005; Mayteniella Maia, 2001; Myrciariamyia Maia, 1995; 
Promikiola Kieffer \& Herbst, 1911; Sphaeramyia Maia, 2007; Uleia Rübsaamen, 1905; Xyloperrisia Kieffer, 1913; and the new genus. Among them, almost all have onetoothed tarsal claws (with exception of Uleia with simple tarsal claws and Xyloperrisia with two-toothed claws). Other characters presented by the new genus are more restricted, such as one-segmented palpi (also present in Guarephila, Haplopalpus, Jorgenseniella, and Mayteniella); slightly bilobed hypoproct (found in Eugeniamyia, Guareamyia, Mayteniella, and Sphaeramyia); reduced larval spatula (also observed in Mayteniella, and Myrciariamyia); reduced pupal prothoracic spiracle (present in Guareamyia, Haplopalpus, Jorgenseniella, Mayteniella, Sphaeramyia, and Xyloperrisia too); absence of pupal antennal horns (shared only by the new genus, Haplopalpus and Mayteniella); lack of pupal dorsal abdominal spines (as in Guareamyia, Jorgenseniella, Mayteniella, Sphaeramyia, and Xyloperrisia). The only character unique to the new genus is the elongatecylindrical female cerci.
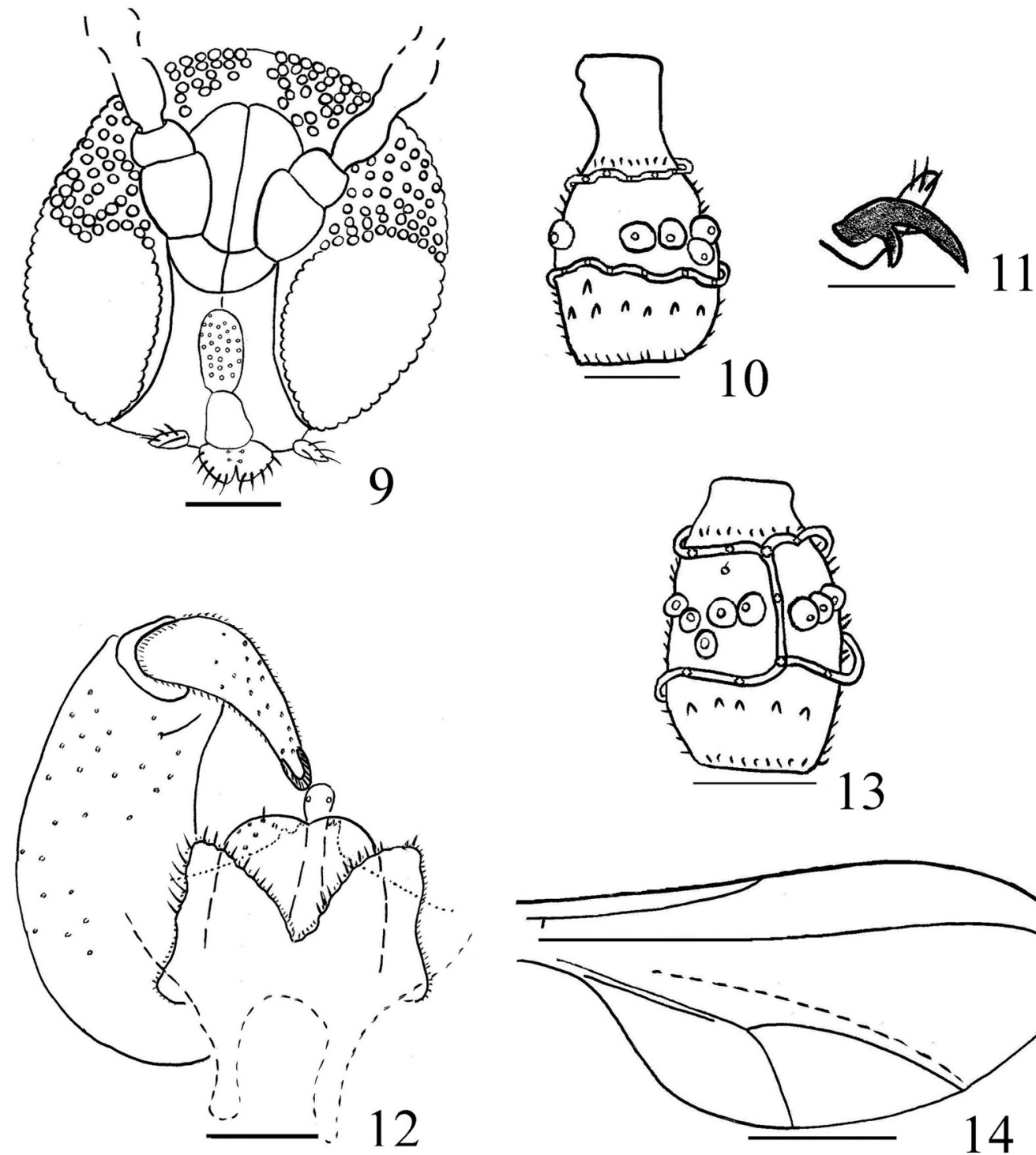

35 of the Gagné key to genera of Neotropical Lasiopteridi (GAGNÉ,1994), but it differs from it as Haplopalpus has bowed, two-toothed tarsal claws, elaborate pupal antennal horns and female cerci without modified setae.

Among all Neotropical unplaced genus of Lasiopteridi, the female of Elachypalpus resembles that of Eugeniamyia as both present short, barely protractible ovipositor, and separate female cerci with strong setae at the apex and otherwise covered with sparse setae. But, the cerci of the new genus are accentually longer than those of Eugeniamyia $(0.11 \mathrm{~mm}$ and $0.03 \mathrm{~mm}$, respectively). Furthermore, the male terminalia of both gallers are quite different (see Figs 5, 14), as well as the larval prothoracic spatula, which is reduced in the new genus.

\section{Elachypalpus psidii sp. nov.} (Figs 9-18)

Adult. Body length: 2.9-3.0 mm in male $(\mathrm{n}=2) ; 3.5$ $\mathrm{mm}$ in female $(\mathrm{n}=1)$.



Figures 9-14. Elachypalpus psidii sp. nov. 9-12, male: 9, head frontal (scale bar: $0.10 \mathrm{~mm}$ ); 10, flagellomere 5 (scale bar: $0.03 \mathrm{~mm}$ ); 11 , midleg, tarsal claw and empodium (scale bar: $0.03 \mathrm{~mm}$ ); 12, terminalia, dorsal (scale bar: $0.05 \mathrm{~mm}$ ). 13, 14, fêmea: 13, flagellomere 5 (scale bar: $0.04 \mathrm{~mm}$ ); 14, wing (scale bar: $0.50 \mathrm{~mm}$ ). 
Head (Fig. 9): post occipital peak absent; antennae: scape obconic; pedicel globose; male flagellomeres with long neck (total length of flagellomere 5: $0.11 \mathrm{~mm}$; length of flagellomere neck: $0.03 \mathrm{~mm}$, Fig. 10); female flagellomeres with short neck (total length of flagellomere 5: 0.11; length of flagellomere neck: $0.02 \mathrm{~mm}$, Fig. 13); necks bare and nodes setulose. Flagellomeres 1 and 2 connate. Number of flagellomeres: $9+$ ? (antennae broken). Palpus one-segmented. Thorax: anepimeron setose, other pleural sclerites asetose. Wing (Fig. 14) length: $2.1 \mathrm{~mm}$ in male $(\mathrm{n}=1) ; 2.0 \mathrm{~mm}$ in female $(\mathrm{n}=1)$. Tarsal bent near base, empodium longer than bent in claws (Fig. 11). Male abdomen: tergites 1-7 rectangular with a single, complete row of caudal setae, some lateral setae, two anterior trichoid sensilla and elsewhere with scattered scales. Tergite 8 band-like with only two anterior trichoid sensilla as vestiture. Sternites 2-7 rectangular and setose, setae more abundant anteriorly and mesally, and two anterior trichoid sensilla. Sternite 8 rectangular with scattered setae and two anterior trichoid sensilla. Female abdomen: tergites 1-8 rectangular, all with a single, complete row of caudal setae, some lateral setae, two anterior trichoid sensilla and elsewhere with scattered scales. Sternites 2-7 as in male. Sternite 8 not sclerotized. Male terminalia (Fig. 12): gonocoxite $0.18-0.20 \mathrm{~mm}$ of length $(\mathrm{n}=2)$; gonostylus $0.10-0.11 \mathrm{~mm}$ of length; lobes cercal with irregular margin, hypoproct longer than cercus; aedeagus thin, with rounded and slightly wider apex. Female cerci cylindrical, $0.11 \mathrm{~mm}$ of length and $0.03 \mathrm{~mm}$ of width (Fig. 15).

Pupa. In bad conditions. Body weakly sclerotized. Antennal horn triangular (Fig. 16).

Larva. Color: white. Body elongate, cylindrical, tapered at both ends, more prominent at anterior end. Length: 1.45-1.60 mm $(\mathrm{n}=2)$. Integument rough. Spatula $0.035 \mathrm{~mm}$ long $(\mathrm{n}=2)$, with two triangular apical teeth about $0.008 \mathrm{~mm}$ long and reduced stalk; a single setose lateral papillae per side (Fig. 17). Terminal segment convex, with two well developed setose terminal papillae (Fig. 18).


Figures 15-18. Elachypalpus psidii sp. nov. 15, female cerci, ventral (scale bar: $0.05 \mathrm{~mm}$ ); 16, pupa, antennal horn (scale bar: $0.10 \mathrm{~mm}$ ); 17, larva, prothoracic spatula, ventral (scale bar: $0.05 \mathrm{~mm}$ ); 18, larva, terminal segment (scale bar: $0.05 \mathrm{~mm}$ ). 
Type material. Holotype $\sigma^{7}$, BRAZIL, Rio Grande do Sul: Pelotas, 30.X.2008, D. Nava col. (MNRJ). Paratypes: 10, same data as holotype; 29,1 pupal exuvia, 31.X.2008; 3 larvae, 03.XII.2008; 10', 19, 26.IX.2009. Obtained from cylindrical leaf galls on Psidium cattleianum.

Etymology. The name psidii refers to the name of the host plant species.

Acknowledgments. To CNPq for financial support (Proc. 472084/2007-0 and 301197/2007-5), Dr. Maria Antonieta P. de Azevedo (Museu Nacional/UFRJ) and Adriana Neutzling Bierhals (EMBRAPA, Pelotas) for helping us during field works.

\section{REFERENCES}

GaGnÉ, R. J. 1989. The plant-feeding gall midges of North America. Ithaca, Cornell University. 356p.

1994. The gall midges of the Neotropical region. Ithaca, Cornell University. 352p.

2004. A catalog of the Cecidomyiidae (Diptera) of the world. Memoirs of the Entomological Society of Washington 25:1-408.

Hodges, C. S. 1988. Preliminary exploration for potential biological control agents for Psidium cattleianum. Technical
Report 66. Honolulu, Cooperative National Park Resources Studies Unit. University of Hawaii. 32p.

HouARD, C. 1933. Les Zoocécidies des Plantes de l'Amérique du Sud et de l'Amerique Central. Paris, Hermann. 549p.

MaIA, V. C. 2001. The gall midges (Diptera, Cecidomyiidae) from three restingas of Rio de Janeiro State, Brazil. Revista Brasileira de Zoologia 18:583-629.

Maia, V. C.; Magenta, M. A. G. \& Martins, S. E. 2008. Ocorrência e caracterização de galhas de insetos em áreas de restinga de Bertioga (São Paulo, Brasil). Biota Neotropica 8:167-197.

Maia, V. C.; Mendonça-Júnior, M. DE S. \& Romanowski, H. P. 1996. Eugeniamyia dispar gen. n. and sp. n. (Diptera, Cecidomyiidae, Lasiopteridi) associated with Eugenia uniflora L. (Myrtaceae) in Brazil. Revista Brasileira de Zoologia 13:1087-1090.

Marchiori, J. N. C. \& Sobral, M. 1997. Dendrologia das Angiospermas: Myrtales. Santa Maria, UFSM. 304p.

McAlpine, J. F. 1981. Manual of Nearctic Diptera. Quebec, Research Branch Agriculture of Canada. v.1, 674p.

Reitz, P. R.; Klein, R. M. \& Reis, A. 1983. Flora Catarinense (Psidium). Sellowia 35:684-715.

RüBSAAMEN, E. H. 1917. Beiträg zur Kenntnis aussereuropäischer Zoocecidien. III. Beitrag: Gallen aus Brasilien und Peru. Marcellia 6:110-173.

Wikler, C. 2007. A cecídia-do-ramo do araçazeiro. In: PedrosaMacedo, J. H.; DalMolin, A. \& Smith, C. W. eds. O Araçazeiro: ecologia e controle biológico. Curitiba, FUPEF. p.163-196.

Recebido em março de 2010. Aceito em março de 2011. ISSN 0073-4721

Artigo disponível em: www.scielo.br/isz 